\title{
Hypodipsic-hypernatremia syndrome in an adult with polycythemia: a case report
}

\author{
Mogamat-Yazied Chothia ${ }^{{ }^{*}}$ (D), Kiran George ${ }^{2}$, Muhammed Sheik ${ }^{2}$ and Mogamat Razeen Davids ${ }^{1}$
}

\begin{abstract}
Background: Hypernatremia is a very common electrolyte disorder and is frequently encountered in out-patient as well as in-hospital settings. We describe an adult who was found to have unexplained relative polycythemia and episodic hypernatremia. A diagnosis of idiopathic hypodipsic-hypernatremia syndrome was made and the patient was managed with a water-drinking schedule.

Case presentation: A 24-year-old South African-Indian man was found to have polycythemia in association with episodes of hypernatremia. Investigations indicated that he had relative polycythemia. He experienced no thirst at a time when his serum sodium concentration was found to be $151 \mathrm{mmol} / \mathrm{L}$. Further testing indicated that his renal response to arginine vasopressin was intact and magnetic resonance imaging of his brain revealed no hypothalamic lesions. A diagnosis of idiopathic hypodipsic-hypernatremia syndrome was made and he was managed with a water-drinking schedule that corrected his hypernatremia.

Conclusion: Hypodipsia should always be considered when a patient without physical or cognitive disability presents with unexplained episodic hypernatremia or with relative polycythemia.
\end{abstract}

Keywords: Idiopathic, Hypodipsia, Hypernatremia, Polycythemia

\section{Background}

Hypernatremia (serum sodium concentration > 145 $\mathrm{mmol} / \mathrm{L}$ ) is a very common electrolyte disorder and is frequently encountered in out-patient as well as in-hospital settings $[1,2]$. Since the main determinant of serum osmolality is the serum sodium concentration, changes in the concentration of the latter reflect changes in serum osmolality. Osmoreceptors in the hypothalamus respond to changes in serum osmolality by stimulating or inhibiting the sensation of thirst, as well as by controlling the release of arginine vasopressin (AVP) from the neurohypophysis. The latter is a critical element in the renal conservation or excretion of water. Thus, hypernatremia indicates dysfunction of the control mechanisms for serum osmolality. In those without physical and/or cognitive disabilities, the presence of chronic hypernatremia invariably indicates an inability to sense thirst. In fact, studies conducted in patients

\footnotetext{
* Correspondence: yaziedc@sun.ac.za

'Division of Nephrology, Department of Medicine, Tygerberg Hospital and Stellenbosch University, Ward A7, Tygerberg Hospital, Francie van Zijl Drive, Parow Valley, Cape Town 7505, South Africa

Full list of author information is available at the end of the article
}

with diabetes insipidus have found that the severity of hypernatremia was dependent on the ability to sense thirst [3]. Isolated hypodipsia with an intact AVP response is a very rare phenomenon. It may be caused by congenital or acquired disease affecting the hypothalamic area and includes conditions such as vascular malformations, malignancies, trauma, and granulomatous disease $[4,5]$.

We describe an adult who was found to have unexplained relative polycythemia and episodic hypernatremia. Following numerous investigations, it became clear that the patient was not able to sense thirst whereas the renal response to AVP was intact. A diagnosis of idiopathic hypodipsic-hypernatremia syndrome was made and the patient was managed with a water-drinking schedule. To the best of our knowledge, this case represents a first description of hypodipsic-hypernatremia syndrome presenting with unexplained relative polycythemia.

\section{Case presentation}

A 24-year-old South African-Indian man, a medical student, had presented 6 years earlier to his peripheral 
hospital with complaints of lethargy and weakness, chronic constipation and lower backache, and episodes of hematochezia, associated with anorectal pain. These symptoms started 18 months earlier. The clinical examination was unremarkable. Routine blood tests were otherwise normal except for marked polycythemia (Table 1). A colonoscopy was performed, and a biopsy taken from a sessile rectal polyp; however, no specific pathological diagnosis could be made, and he was referred to our center for further management.

At our gastroenterology clinic, the initial presentation together with a review of the rectal biopsy were considered suggestive of ulcerative colitis and he was initiated on 5-aminosalicylic acid and, later, sulfasalazine. However, the symptoms did not improve, and these drugs were stopped. During this time, it was noticed that his blood pressure was $156 / 86 \mathrm{mmHg}$, and treatment with enalapril was initiated. After a period of approximately 4 months, the enalapril was stopped because he had no evidence of left ventricular hypertrophy on an electrocardiogram or echocardiography and 24-hour ambulatory blood pressure monitoring was normal. A repeat colonoscopy was performed, this time revealing rectal prolapse. The gastrointestinal symptoms resolved completely without the need for further medication.

During this period, he was also investigated for the polycythemia at our hematology clinic. A blood test for the Janus kinase-2 (V617F) mutation was negative and the blood erythropoietin concentration was normal (Table 1), hence, excluding primary polycythemia. Due to the severity of the polycythemia, he received frequent venesections that resulted in lethargy, and the venesections were subsequently stopped. Other investigations for true polycythemia were normal and included: a venous blood gas to determine the P50 value for hemoglobin oxygen affinity; echocardiography to rule out congenital cyanotic heart disease; polysomnography for obstructive sleep apnea syndrome; and an abdominal ultrasound for hepatocellular carcinoma, polycystic kidney disease, renal cell carcinoma, and renal arterial stenosis. A radioisotope study showed that the red cell mass was within the normal range; however, the plasma

Table 1 The patient's serum and urine biochemistry results

\begin{tabular}{|c|c|c|c|c|c|c|c|c|c|c|c|}
\hline & Ref range & $\begin{array}{l}\text { Aug } \\
2012\end{array}$ & $\begin{array}{l}\text { Nov } \\
2015\end{array}$ & $\begin{array}{l}\text { Jan } \\
2016\end{array}$ & $\begin{array}{l}\text { Mar } \\
2016\end{array}$ & $\begin{array}{l}\text { May } \\
2016\end{array}$ & $\begin{array}{l}\text { Jun } \\
2016\end{array}$ & $\begin{array}{l}\text { Feb } \\
2017\end{array}$ & $\begin{array}{l}\text { Jul } \\
2018\end{array}$ & $\begin{array}{l}\text { Aug } \\
2018^{a}\end{array}$ & $\begin{array}{l}\text { Sep } \\
2018^{b}\end{array}$ \\
\hline \multicolumn{12}{|l|}{ Serum } \\
\hline Sodium & $138-145 \mathrm{mmol} / \mathrm{L}$ & 154 & 147 & 144 & 144 & 143 & 142 & 143 & 147 & 151 & 141 \\
\hline Potassium & $3.3-5.3 \mathrm{mmol} / \mathrm{L}$ & 5.1 & 5 & 4.6 & 4.9 & 4.8 & 5 & 4.4 & 4.6 & 5.5 & \\
\hline Urea & $2.1-7.1 \mathrm{mmol} / \mathrm{L}$ & 6.4 & 5.5 & 5 & 3.8 & 4.1 & 5.8 & 4.6 & 5.9 & 3.9 & 4.9 \\
\hline Creatinine & 64-104 umol/L & & 107 & 94 & 101 & 93 & 89 & 106 & 110 & 99 & 92 \\
\hline $\begin{array}{l}\text { Unadjusted } \\
\text { calcium }\end{array}$ & $2.15-2.50 \mathrm{mmol} / \mathrm{L}$ & & & & & & 2.52 & & 2.56 & 2.72 & 2.43 \\
\hline lonized calcium & $1.1-1.3 \mathrm{mmol} / \mathrm{L}$ & & & & & & & & 1.21 & & \\
\hline Leukocyte count & $4.0-10.0 \times 10^{9} / \mathrm{L}$ & 8.6 & 10.8 & & 9.0 & 8.0 & 8.2 & 10.1 & 12.9 & 8.9 & 8.8 \\
\hline Hemoglobin & $13.0-17.0 \mathrm{~g} / \mathrm{dL}$ & 17.8 & 19.3 & & 19.1 & 18.5 & 18.8 & 18.6 & 20.2 & 19.0 & 18.1 \\
\hline Hematocrit & $0.40-0.50$ & 0.55 & 0.60 & & 0.60 & 0.56 & 0.58 & 0.58 & 0.69 & 0.63 & 0.58 \\
\hline Mean cell volume & $79.1-98.9 \mathrm{fL}$ & 84.9 & 81.1 & & 85.1 & 84 & 85.4 & 85.8 & 85.9 & 86.1 & 84.1 \\
\hline Platelets & $137-373 \times 10^{9} / \mathrm{L}$ & 279 & 305 & & 227 & 215 & 234 & 287 & 313 & 301 & 280 \\
\hline Albumin & $35-52 \mathrm{~g} / \mathrm{L}$ & 52 & & & & & & & 52 & & \\
\hline Erythropoietin & $2.6-18.5 \mathrm{U} / \mathrm{L}$ & & 10.7 & & & & & & & & \\
\hline 25-OH-vitamin D & $>72.5 \mathrm{nmol} / \mathrm{L}$ & & & & & $<10.5$ & & & & & \\
\hline PTH & 2-7 pmol/L & & & & & & & & & 3.6 & \\
\hline Renin & 2-24 ng/L & & & & & & & & & 45.6 & \\
\hline Aldosterone & 50-640 pmol/L & & & & & & & & & 176 & \\
\hline Cortisol & $130-530 \mathrm{nmol} / \mathrm{L}$ & & & & & & & & & 130 & \\
\hline \multicolumn{12}{|l|}{ Urine } \\
\hline Sodium & $\mathrm{mmol} / \mathrm{L}$ & & & 174 & & & & & & & \\
\hline Osmolality & $\begin{array}{l}50-1200 \mathrm{mOsm} / \\
\mathrm{kg} \cdot \mathrm{H}_{2} \mathrm{O}\end{array}$ & & & 1040 & & & 792 & & & & 763 \\
\hline
\end{tabular}

Abbreviations: Unadj.calcium unadjusted calcium, 25-OH vitamin D 25-hydroxy vitamin D, PTH parathyroid hormone a Date of nephrology consultation

${ }^{\mathrm{b}}$ Nephrology consultation following 1 week of $\sim 2$ litres per day of water drinking 
volume was reduced, suggesting relative polycythemia. After approximately 5 years, he was referred to the nephrology unit for further investigation.

At this time, there were no symptoms of nausea, vomiting, diarrhea, polyuria, or nocturia. Once again, he confirmed that he never felt thirsty, even during the previous episodes of hypernatremia. He drank water out of habit rather than in response to thirst. He was not using any prescription drugs, including diuretics. His family history included a father with diabetes mellitus and hypercholesterolemia and a mother with hypertension. He did not smoke tobacco or consume alcohol. He led a relatively sedentary lifestyle and did not participate in any outdoor recreational activities. He was in his final year of medical school training. A clinical examination was unremarkable. He was euvolemic and there was no evidence of postural hypotension. No cognitive or focal neurological deficits were identified. A urine dipstick was normal. His weight was $96 \mathrm{~kg}$ and height $1.70 \mathrm{~m}$ (calculated body mass index of $33.2 \mathrm{~kg} / \mathrm{m}^{2}$ ). Bioimpedance spectroscopy (Body Composition Monitor ${ }^{\bullet}$, Fresenius Medical Care, Germany) was used to further assess his hydration status and revealed a total body water volume which was $800 \mathrm{~mL}$ less than predicted.

A blood sample for serum sodium concentration was drawn and revealed a value of $151 \mathrm{mmol} / \mathrm{L}$ (reference range $138-145 \mathrm{mmol} / \mathrm{L}$; see Table 1). Previous urine osmolality samples showed excellent urinary concentrating ability, thereby excluding a diagnosis of diabetes insipidus. A diagnosis of hypodipsia was made, and he was asked to drink 2 liters of water daily for 1 week. Blood and urine samples were then repeated and revealed normalization of the serum sodium concentration while maintaining urinary concentrating ability, thus confirming our suspicion of hypodipsia (Table 1). Since hypodipsia has been reported to be the result of a hypothalamic lesion, magnetic resonance imaging of his brain was performed but no intracranial pathology was identified (Fig. 1). He was instructed to continue drinking at least 2 liters of water daily. On follow-up 6 weeks later, he remained clinically well and did not report any significant change in his symptoms.

\section{Discussion}

We present a challenging case of episodic hypernatremia and associated relative polycythemia that after a protracted period and following numerous investigations was found to have idiopathic hypodipsia. Frequently causes of relative polycythemia include diuretics, vomiting, and diarrhea [6]. To the best of our knowledge, this is the first description of hypodipsic-hypernatremia syndrome presenting with relative polycythemia.

Hypodipsic-hypernatremia syndrome is a rare disorder of reduced or absent thirst sensation. It frequently

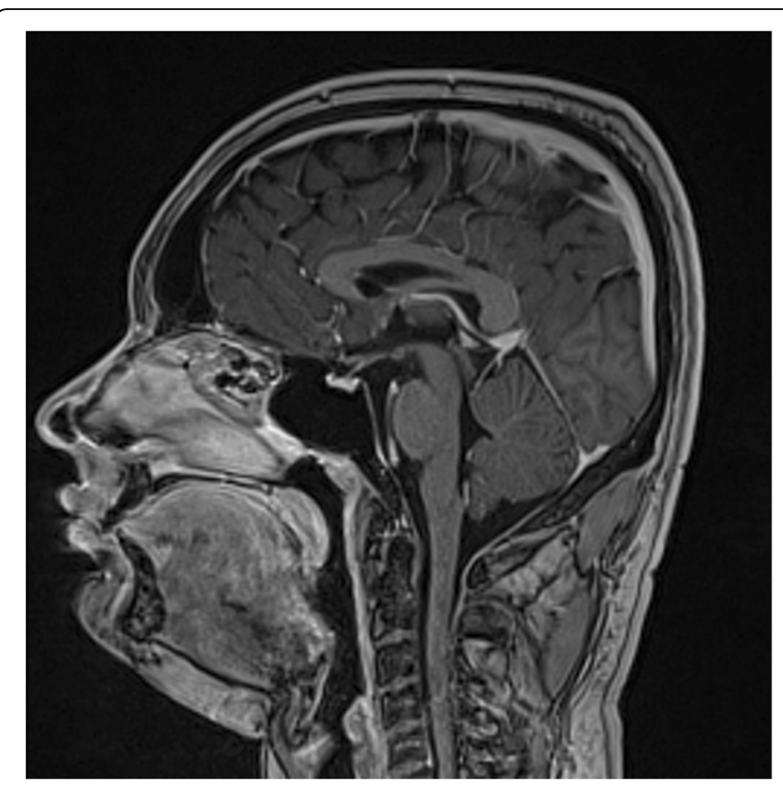

Fig. 1 Magnetic resonance image of the brain (sagittal view) showing the absence of a hypothalamic lesion

presents with recurrent episodes of hypernatremia in children or adults and may be caused by congenital or acquired neurological disorders. To the best of our knowledge, this is the first description of an adult who presented with unexplained polycythemia.

Hypernatremia may result from a gain of sodium or a loss of water. The former frequently occurs in critically ill, hospitalized patients who receive excessive amounts of intravenously administered isotonic fluids, while the latter occurs in the out-patient setting, usually due to conditions such as diarrhea. Regardless of the underlying mechanism, the presence of hypernatremia indicates dysfunction of the normal control mechanisms for water balance. A group of specialized hypothalamic cells function as osmoreceptors and, during hypernatremia, shrinks because of the efflux of water. This triggers the release of neuronal signals to the thirst center and the posterior pituitary gland [7]. Stimulation of the thirst center leads to increased water intake, and the release of AVP causes renal water retention and the excretion of a small volume of maximally concentrated urine [7].

Our patient was not critically ill and did not have a condition that caused excessive gastrointestinal or renal water losses, or which prevented him from gaining access to water. Therefore, a search for dysfunction of the water control axis was undertaken.

Following numerous investigations that eliminated causes of true polycythemia, the presence of reduced total body water, and hence relative polycythemia, was confirmed using radioisotope-labeled red blood cells and albumin-labeled plasma, as well as bioimpedance spectroscopy. Additional evidence that supported hypovolemia 
Table 2 Reported cases of hypodipsic-hypernatremia with intact arginine vasopressin response

\begin{tabular}{|c|c|c|c|c|c|c|c|c|}
\hline Case & $\begin{array}{l}\text { Age at } \\
\text { diagnosis } \\
\text { (years) }\end{array}$ & Sex & $\begin{array}{l}\text { Serum sodium } \\
\text { concentration } \\
(\mathrm{mmol} / \mathrm{L})\end{array}$ & $\begin{array}{l}\text { Urine } \\
\text { osmolality } \\
\text { (mOsm/ } \\
\mathrm{kg})\end{array}$ & $\begin{array}{l}\mathrm{Hb}(\mathrm{g} / \mathrm{dL}) \\
/ \mathrm{Hct}(\%)\end{array}$ & AVP concentration $(\mathrm{pg} / \mathrm{ml})$ & Final diagnosis & Treatment \\
\hline $\begin{array}{l}\text { Conley et al., } \\
1976[20]\end{array}$ & 7 & $\mathrm{~F}$ & 194 & 1129 & NR & ND & Idiopathic & $\begin{array}{l}\text { Water-drinking } \\
\text { schedule }\end{array}$ \\
\hline $\begin{array}{l}\text { Powell et al., } \\
1983 \text { [12] }\end{array}$ & 9 & M & $145-165$ & $>1000$ & $-/ 44.6$ & ND & $\begin{array}{l}\text { Possible post-viral } \\
\text { hypothalamic } \\
\text { dysfunction }\end{array}$ & $\begin{array}{l}\text { Diuretics } \\
\text { Salt restriction } \\
\text { Pitressin } \\
\text { (vasopressin) } \\
\text { Water-drinking } \\
\text { schedule }\end{array}$ \\
\hline $\begin{array}{l}\text { Farley et al., } \\
1986 \text { [13] }\end{array}$ & 17 & M & 181 & 645 & NR & $\begin{array}{l}\text { Normal response to saline } \\
\text { infusion }\end{array}$ & Schizophrenia & $\begin{array}{l}\text { Treatment of } \\
\text { psychosis }\end{array}$ \\
\hline $\begin{array}{l}\text { Hammond et } \\
\text { al., } 1986[5]\end{array}$ & 5 & NR & 150 & $1112-1138$ & $\begin{array}{l}\text { Reported } \\
\text { as normal }\end{array}$ & $\begin{array}{l}14.2-17.3 \\
\text { (free water-drinking and serum } \\
\text { sodium concentration ranging } \\
\text { from } 149 \text { to } 150 \mathrm{mmol} / \mathrm{L} \text { ) }\end{array}$ & Congenital CMV & $\begin{array}{l}\text { Water-drinking } \\
\text { schedule }\end{array}$ \\
\hline $\begin{array}{l}\text { Assadi et al., } \\
1989[14]\end{array}$ & 6 & $\mathrm{~F}$ & 187 & 854 & $14.5 / 43.9$ & 25.6 (water deprivation test) & Head injury & $\begin{array}{l}\text { Water-drinking } \\
\text { schedule }\end{array}$ \\
\hline $\begin{array}{l}\text { Franco-Saenz } \\
\text { et al., } 1989 \\
\text { [23] }\end{array}$ & 22 & M & 181 & 1295 & $-/ 42.8$ & $\begin{array}{l}3.3 \mathrm{pmol} / \mathrm{L} \\
\text { (normal AVP response: > } 3.2 \\
\text { pmol/L when serum osmolality } \\
>302 \mathrm{mOsm} / \mathrm{kg} \text { ) }\end{array}$ & Hydrocephalus & $\begin{array}{l}\text { Intravenous fluids } \\
\text { and forced water- } \\
\text { drinking }\end{array}$ \\
\hline $\begin{array}{l}\text { Phillips and } \\
\text { Gabow, } 1990 \\
\text { [4] }\end{array}$ & 34 & M & 165 & 898 & NR & ND & $\begin{array}{l}\text { Psychotic } \\
\text { depression }\end{array}$ & $\begin{array}{l}\text { Electroconvulsive } \\
\text { therapy }\end{array}$ \\
\hline $\begin{array}{l}\text { Zünd et al., } \\
1998 \text { [22] }\end{array}$ & 45 & M & 171 & 700 & NR & $\begin{array}{l}\text { 3-fold rise in response to thirst } \\
\text { test }\end{array}$ & Stroke & NR \\
\hline $\begin{array}{l}\text { Kang et al., } \\
2001[15]\end{array}$ & 25 & M & 168 & 623 & $11.9 / 35.3$ & $\begin{array}{l}>14.16(1.0-6.7) \text { (water } \\
\text { deprivation test) }\end{array}$ & Brain tumor & $\begin{array}{l}\text { Radiotherapy, } \\
\text { steroids, thyroxine, } \\
\text { water-drinking } \\
\text { schedule }\end{array}$ \\
\hline $\begin{array}{l}\text { López- } \\
\text { Capapé et } \\
\text { al., } 2004 \text { [16] }\end{array}$ & 12 & M & 162 & 1230 & NR & 12.8 (2.5\% salt load) & Idiopathic & $\begin{array}{l}\text { Water-drinking } \\
\text { schedule }\end{array}$ \\
\hline $\begin{array}{l}\text { Ramthun et } \\
\text { al., } 2011 \text { [21] }\end{array}$ & 56 & M & 157 & $1.026(\mathrm{SG})$ & NR & $N R$ & Hemorrhagic stroke & $\begin{array}{l}\text { Water-drinking } \\
\text { schedule }\end{array}$ \\
\hline $\begin{array}{l}\text { Mattai, } 2011 \\
{[17]}\end{array}$ & 36 & $\mathrm{~F}$ & 176 & 1172 & NR & NR & $\begin{array}{l}\text { Craniopharyngioma } \\
\text { or germ cell tumor }\end{array}$ & $\begin{array}{l}\text { Initial treatment } \\
\text { with } 0.45 \% \text { saline } \\
\text { followed by oral } \\
\text { intake }\end{array}$ \\
\hline $\begin{array}{l}\text { Sabzghabaei } \\
\text { and } \\
\text { Rastegar, } \\
2015 \text { [18] }\end{array}$ & 27 & M & 171 & 840 & NR & ND & Idiopathic & $\begin{array}{l}\text { Water-drinking } \\
\text { schedule }\end{array}$ \\
\hline $\begin{array}{l}\text { Manning et } \\
\text { al., } 2017 \text { [19] }\end{array}$ & 56 & M & 181 & 1080 & NR & ND & Psychogenic adipsia & $\begin{array}{l}\text { Water-drinking } \\
\text { schedule } \\
\text { Mirtazapine } \\
\text { Clonazepam }\end{array}$ \\
\hline $\begin{array}{l}\text { Chothia; this } \\
\text { case report }\end{array}$ & 25 & M & $142-154$ & $763-1040$ & $\begin{array}{l}17.8-20.2 \\
/ 55-69\end{array}$ & ND & Idiopathic & $\begin{array}{l}\text { Water-drinking } \\
\text { schedule }\end{array}$ \\
\hline
\end{tabular}

$A V P$ arginine vasopressin, $C M V$ cytomegalovirus, $F$ female, $H b$ hemoglobin, $H c t$ hematocrit, $M$ Male, $N D$ not done, $N R$ not reported, $S G$ specific gravity

included a raised plasma renin concentration and a serum albumin concentration that was at the upper limit of normal. An interesting finding was that of hypercalcemia. This seemed to mirror the changes in serum sodium concentration. Since our laboratory no longer reports adjusted calcium concentrations, the hypercalcemia was thought to be the result of hyperalbuminemia due to hemoconcentration [8]. This was supported by the normal serum ionized calcium concentration, as well as a normal parathyroid hormone concentration. 
AVP is primarily controlled by changes in serum osmolality; however, non-osmotic stimuli may also have an influence on its secretion, albeit to a lesser extent [9]. Cases of hypodipsia have been described where there appeared to be an intact urinary concentrating ability, but with AVP being secreted in response to the non-osmotic stimulus of hypovolemia. However, correction of the hypovolemia resulted in the unmasking of diabetes insipidus [10]. In our patient, the suspicion of isolated hypodipsia was heightened after investigations confirmed that urinary concentrating ability remained intact even after he increased his water intake.

A diagnosis of hypodipsia can readily be made in a patient that denies the sensation of thirst and/or does not spontaneously drink water when the serum sodium concentration is greater than $150 \mathrm{mmol} / \mathrm{L}$ or the serum osmolality is greater than $310 \mathrm{mOsm} / \mathrm{kg}$ [5]. In our patient, 4 out of 10 serum sodium concentrations were greater than $145 \mathrm{mmol} / \mathrm{L}$. The normal serum sodium concentrations were probably due to the timing of the blood samples relative to our patient's water consumption; he reported drinking water out of habit rather than in response to thirst. The diagnosis of hypodipsia can be confirmed by a water deprivation test, which documents the absence of thirst once the serum sodium concentration exceeds $150 \mathrm{mmol} / \mathrm{L}$. In our patient, the serum sodium concentration was found to be $151 \mathrm{mmol} / \mathrm{L}$ at a time when he denied thirst. A formal water deprivation test was therefore not necessary.

Four categories of hypodipsia have been described [11]. In type A, a higher than normal serum osmolality is needed to stimulate thirst and vasopressin release; type $B$ results in inadequate thirst stimulation and vasopressin release and may be caused by conditions that result in partial loss of osmoreceptors; type $\mathrm{C}$ is caused by complete loss of osmoreceptors and therefore complete absence of thirst and vasopressin release. This type frequently occurs following surgery. Our patient was thought to have type D hypodipsia. This rare form presents with isolated hypodipsia but with a normal response to vasopressin. A search of the literature identified only 14 cases and these, together with our case, are summarized in Table $2[4,5,12-23]$. The ages ranged from 5 to 56 years, 11 of the 15 patients were male, serum sodium concentrations ranged from $142 \mathrm{mmol} / \mathrm{L}$ to $194 \mathrm{mmol} / \mathrm{L}$, and urine osmolality ranged from 623 to $1295 \mathrm{mOsm} / \mathrm{kgH}_{2} \mathrm{O}$. Most cases (73\%) had an identifiable cause and included psychiatric conditions $(n=3)$, brain tumors (2), viral infections (2), stroke (2), head trauma (1), and congenital hydrocephalus (1). In four cases, including the current case, no identifiable cause could be found. In those where AVP was measured, a normal response to changes in serum osmolality was reported. Of note, none of the other cases reported polycythemia.
Management involves the prescription of a water-drinking schedule. This may be guided by the patient's weight. Water consumption should be increased during warmer months and during exercise. Since the AVP response to serum osmolality is intact, patients will have a water diuresis in response to excessive intake and there is therefore no risk of water overload and cerebral edema.

Hypodipsic-hypernatremia syndrome seems to have an overall favorable outcome regardless of the underlying cause. In the cases cited in Table 2, there were no deaths reported. In most of the patients, the hypodipsia persisted and was treated with a water-drinking schedule only. Interestingly, in all cases that had an underlying psychiatric diagnosis, the hypodipsia resolved completely following treatment of the underlying condition.

\section{Conclusion}

To the best of our knowledge, this is the first description of hypodipsia-hypernatremia syndrome presenting with unexplained relative polycythemia. Hypodipsia should always be considered when a patient without physical or cognitive disability presents with unexplained episodic hypernatremia or with relative polycythemia.

\section{Abbreviation \\ AVP: Arginine vasopressin; Unadj.calcium, unadjusted calcium; $25-\mathrm{OH}$ vitamin D, 25-hydroxy vitamin D; PTH, parathyroid hormone.}

\section{Acknowledgements}

Not applicable.

Funding

Not applicable.

\section{Availability of data and materials}

Data sharing is not applicable to this article as no datasets were generated or analyzed during the current study.

Authors' contributions

All authors were involved in the drafting and approving the final manuscript.

Ethics approval and consent to participate

Ethics approval was obtained from the Human Research Ethics Committee (HREC) of Stellenbosch University (HREC reference number: C18/10/014) and the patient gave his informed consent to publish the case report.

\section{Consent for publication}

Written informed consent was obtained from the patient for publication of this case report and any accompanying images. A copy of the written consent is available for review by the Editor-in-Chief of this journal.

\section{Competing interests}

The authors declare that they have no competing interests.

\section{Publisher's Note}

Springer Nature remains neutral with regard to jurisdictional claims in published maps and institutional affiliations.

\section{Author details}

${ }^{1}$ Division of Nephrology, Department of Medicine, Tygerberg Hospital and Stellenbosch University, Ward A7, Tygerberg Hospital, Francie van Zijl Drive, Parow Valley, Cape Town 7505, South Africa. ${ }^{2}$ Division of General Medicine, 
Department of Medicine, Tygerberg Hospital and Stellenbosch University, Cape Town, South Africa.

Received: 2 November 2018 Accepted: 28 November 2018

Published online: 27 December 2018

\section{References}

1. Palevsky PM, Bhagrath R, Greenberg A. Hypernatremia in hospitalized patients. Ann Intern Med. 1996;124:197-203.

2. Halperin ML, Goldstein MB, Kamel KS. Fluid, Electrolyte and Acid-Base Physiology E-Book: A Problem-Based Approach. Philadelphia: Elsevier Health Sciences; 2010.

3. Thompson C, Baylis P. Thirst in diabetes insipidus: clinical relevance of quantitative assessment. QJM: Int J Med. 1987;65:853-62.

4. Phillips MG, Gabow PA. Psychogenic adipsia in a patient with psychotic depression. Am J Kidney Dis. 1990;15:592-4.

5. Hammond DN, Moll GW, Robertson GL, Chelmicka-Schorr E. Hypodipsic hypernatremia with normal osmoregulation of vasopressin. N Engl J Med. 1986:315:433-6.

6. Keohane C, McMullin MF, Harrison C. The diagnosis and management of erythrocytosis. BMJ. 2013;347:f6667.

7. Verbalis JG. How does the brain sense osmolality? J Am Soc Nephrol. 2007; 18:3056-9.

8. Lian IA, Åsberg A. Should total calcium be adjusted for albumin? A retrospective observational study of laboratory data from central Norway. BMJ Open. 2018;8:e017703.

9. Schrier RW, Goldberg J. The physiology of vasopressin release and the pathogenesis of impaired water excretion in adrenal, thyroid, and edematous disorders. Yale J Biol Med. 1980;53:525.

10. DeRubertis FR, Michelis MF, Beck N, Field JB, Davis BB. "Essential" hypernatremia due to ineffective osmotic and intact volume regulation of vasopressin secretion. J Clin Invest. 1971;50:97-111.

11. McKenna K, Thompson C. Osmoregulation in clinical disorders of thirst appreciation. Clin Endocrinol. 1998:49:139-52.

12. Powell D, Codd M, Skrabanek P, Tempany E. The hypodipsia-hypernatraemia syndrome presenting with obesity. Ir J Med Sci. 1983;152:357-9.

13. Farley $P C$, Lau K-Y, Suba S. Severe hypernatremia in a patient with psychiatric illness. Arch Intern Med. 1986;146:1214-5.

14. Assadi FK, Johnston B, Dawson M, Sung B. Recurrent hypertonic dehydration due to selective defect in the osmoregulation of thirst. Pediatr Nephrol. 1989:3:438-42.

15. Kang MJ, Yoon KH, Lee SS, Lee JM, Ahn YB, Chang SA, Kang MI, Cha BY, Lee KW, Son HY. Hypodipsic hypernatremia with intact AVP response to nonosmotic stimuli induced by hypothalamic tumor: a case report. J Korean Med Sci. 2001;16:677.

16. López-Capapé M, Golmayo L, Lorenzo G, Gallego N, Barrio R. Hypothalamic adipic hypernatraemia syndrome with normal osmoregulation of vasopressin. Eur J Pediatr. 2004;163:580-3.

17. Mattai SAD. Hypernatremia Reviewed: A Case of Hypodipsic Hypernatremia in a Young Woman. Proc UCLA Healthc. 2011:15:1-11.

18. Sabzghabaei F, Rastegar A. Adipsic hypernatremic myopathy. Iran J Kidney Dis. 2015:9:256-8.

19. Manning S, Shaffie R, Arora S. Case Report: Severe hypernatremia from psychogenic adipsia. F1000Res. 2017;6:34.

20. Conley SB, Brocklebank JT, Taylor IT, Robson AM. Recurrent hypernatremia: a proposed mechanism in a patient with absence of thirst and abnormal excretion of water. J Pediatr. 1976;89:898-903.

21. Ramthun M, Mocelin AJ, Alvares Delfino VD. Hypernatremia secondary to poststroke hypodipsia: just add water! Nephrol Dial Transplant Plus. 2011:4:236-7.

22. Zünd S, Fretz C, Krapf R. Acquired disorder of thirst perception with intact osmoregulation of vasopressin. Wien Klin Wochenschr. 1998;110:538-41.

23. Franco-Saenz R, Wolffing BK, Rivers RJ. Case report: Hypodipsia and hypernatremia in congenital hydrocephalus. Am J Med Sci. 1989;297:385-6.

Ready to submit your research? Choose BMC and benefit from:

- fast, convenient online submission

- thorough peer review by experienced researchers in your field

- rapid publication on acceptance

- support for research data, including large and complex data types

- gold Open Access which fosters wider collaboration and increased citations

- maximum visibility for your research: over $100 \mathrm{M}$ website views per year

At $\mathrm{BMC}$, research is always in progress.

Learn more biomedcentral.com/submissions 